\title{
Molecular structure of 8-hydroxy-1-methylquinolinium iodide hydrate in crystal and solution
}

\author{
Piotr Barczyński, Anna Komasa, Małgorzata Ratajczak-Sitarz, \\ Andrzej Katrusiak, Bogumil Brzezinski * \\ Faculty of Chemistry, Adam Mickiewicz University, ul Grunwaldzka 6, 60-780 Poznań, Poland
}

Received 12 December 2005; accepted 5 January 2006

Available online 28 February 2006

\begin{abstract}
8-Hydroxy-1-methylquinolinium iodide monohydrate $\left[\left(\mathrm{C}_{10} \mathrm{H}_{10} \mathrm{NO}\right){ }^{+} \mathrm{I}^{-} \cdot \mathrm{H}_{2} \mathrm{O}\right]$ has been studied by X-ray diffraction, FT-IR, ${ }^{1} \mathrm{H}$ and ${ }^{13} \mathrm{C}$ NMR spectroscopy. In the crystalline state, the iodide anion is hydrogen-bonded to the water molecule, which in turn is hydrogen bonded to the 8-OH group of the 8-hydroxyquinolinium ring, forming of a symmetric dimer. In acetonitrile and DMSO- $d_{6}$ the hydrate assumes a new structure due to almost complete dissociation of the water molecule from the complex structure. In acetonitrile the 8-OH group is hydrogen-bonded to the iodide anion, whereas in DMSO- $d_{6}$ it forms the hydrogen bond with the solvent molecules. This $8-\mathrm{OH} \cdots \mathrm{O}\left(\mathrm{DMSO}-d_{6}\right)$ hydrogen bond is the strongest within the structure of the hydrate.
\end{abstract}

(C) 2006 Elsevier B.V. All rights reserved.

Keywords: 8-Hydroxy-1-methylquinolinium cation; Intermolecular hydrogen bonds; Halides; X-ray structure; Hydrates; FT-IR; ${ }^{1} \mathrm{H}$ NMR; ${ }^{13} \mathrm{C}$ NMR

\section{Introduction}

Recently, we have studied a series of hydrogen-bonded complexes formed between biphenols and 7-methyl-1,5,7triazabicyclo[4.4.0]dec-5-ene (MTBD) hydrogen halogenides ( $\mathrm{HF}, \mathrm{HCl} \mathrm{HBr}$ and $\mathrm{HI}$ ) [1-4]. It has been demonstrated that MTBD-HX molecules ( $\mathrm{X}=\mathrm{F}, \mathrm{Cl}, \mathrm{Br}$ or I) form complexes with biphenols, and that the halogenide anions play a very important role in the arrangement of the molecular structure of the complexes. Other types of phenols, such as 5-, 6-, 7- or 8-hydroxyquinolines, were also shown to form complexes with halogenide anions after their $\mathrm{N}$-alkylation [5-10]. The main interest in the 8-hydroxyquinoline derivatives stems from their ability to form complexes with a wide number of metal cations as well as biological activities, especially disinfectant effects $[11,12]$.

In this paper, the complex formation properties of 8-hydroxy-1-methylquinolinium iodide have been studied by X-ray crystallography, FT-IR and NMR spectroscopic methods.

\footnotetext{
* Corresponding author. Tel.: +48618291330; fax: +48618658008. E-mail address: bbrzez@main.amu.edu.pl (B. Brzezinski).
}

\section{Experimental}

8-Hydroxy-1-methylquinolinium iodide was prepared following the method described by Saxena et al. [10,13,14]. The crystals of 8-hydroxy-1-methyl-quinolinium iodide monohydrate were formed from $96 \%$ ethanol by slow evaporation at room temperature under argon atmosphere. The melting point: $168{ }^{\circ} \mathrm{C}$; the elementary analyses found: $\mathrm{N} 4.51 \%, \mathrm{C} 39.20 \%, \mathrm{H}$ $3.94 \%$, and calculated (for $\mathrm{C}_{10} \mathrm{H}_{10} \mathrm{ION} \cdot \mathrm{H}_{2} \mathrm{O}$ ): $\mathrm{N} 4.59 \%, \mathrm{C}$ $39.34 \%$, H $3.93 \%$.

\subsection{X-ray measurements}

The crystals have the form of yellow parallelepipeds with well developed faces. They were stable at normal conditions and therefore the X-ray diffraction measurements were carried out on a Kuma KM-4 CCD diffractometer at room temperature. The structure was solved by direct methods [15] and refined by full-matrix least squares [16]. Only $\mathrm{H}$-atoms at $\mathrm{O}(1 \mathrm{~W})$ were located from difference Fourier maps and refined with isotropic temperature factors, all the other $\mathrm{H}$-atoms were calculated from molecular geometry and their $U_{\mathrm{iso}} \mathrm{s}$ related to the thermal vibrations of their carriers. The crystal data and details of the $\mathrm{X}$-ray analysis are given in Table 1, the fractional atomic coordinates are listed in Table 2. 
Table 1

Crystal data and structure refinement

\begin{tabular}{|c|c|}
\hline Empirical formula & $\mathrm{C}_{10} \mathrm{H}_{10} \mathrm{INO} \cdot \mathrm{H}_{2} \mathrm{O}$ \\
\hline Formula weight & 305.11 \\
\hline Temperature $(\mathrm{K})$ & 293(2) \\
\hline Wavelength & $0.71073 \AA$ \\
\hline Crystal system, space group & Triclinic, $P \overline{1}$ \\
\hline \multirow[t]{6}{*}{ Unit cell dimensions } & $a=7.9212(12) \AA$ \\
\hline & $b=7.9478(11) \AA$ \\
\hline & $c=9.5335(12) \AA$ \\
\hline & $\alpha=90.801(11)^{\circ}$ \\
\hline & $\beta=107.106(13)^{\circ}$ \\
\hline & $\gamma=98.817(12)^{\circ}$ \\
\hline Volume & $565.75(14) \AA^{3}$ \\
\hline$Z$ & 2 \\
\hline Calculated density & $1.791 \mathrm{~g} \mathrm{~cm}^{-3}$ \\
\hline Absorption coefficient & $2.806 \mathrm{~mm}^{-1}$ \\
\hline$F(000)$ & 296 \\
\hline Crystal size & $0.40 \times 0.25 \times 0.15 \mathrm{~mm}$ \\
\hline$\theta$ Range for data collection & $2.73-29.99^{\circ}$ \\
\hline Limiting indices & $\begin{array}{l}-10 \leq h \leq 10,-10 \leq k \leq 10 \\
-11 \leq l \leq 13\end{array}$ \\
\hline Reflections collected/unique & $5456 / 2879 R_{\mathrm{int}}=0.0777$ \\
\hline Completeness to $\theta=29.99$ & $87.1 \%$ \\
\hline Refinement method & Full-matrix least-squares on $F^{2}$ \\
\hline Data/restraints/parameters & $2879 / 5 / 135$ \\
\hline Goodness-of-fit on $F^{2}$ & 1.012 \\
\hline Final $R$ indices $[I>2 \sigma(I)]$ & $R_{1}=0.0658, w R_{2}=0.1805$ \\
\hline$R$ indices (all data) & $R_{1}=0.0878, w R_{2}=0.1961$ \\
\hline Largest diff. peak and hole & 1.959 and $-2.227 \mathrm{e}^{-3}$ \\
\hline
\end{tabular}

The crystallographic-information-file (CIF) has been deposited with the Cambridge Crystallographic Database Center as a supplementary publication no. CCDC 291623.

\subsection{Spectroscopic measurements}

The IR spectra of the 8-hydroxy-1-methylquinolinium iodide monohydrate were recorded in nujol/fluorolube and $\mathrm{KBr}$ pellets $(1.5 / 200 \mathrm{mg})$ as well as in acetonitrile solution at $300 \mathrm{~K}$ on a Bruker IFS 113v spectrometer (DTGS detector,

Table 2

Atomic coordinates $\left(\times 10^{4}\right)$ and equivalent isotropic displacement parameters $\left(\AA^{2} \times 10^{3}\right)$

\begin{tabular}{lrlll}
\hline & \multicolumn{1}{l}{$y$} & $z$ & $U(\mathrm{eq})$ \\
\hline $\mathrm{O}(1 \mathrm{~W})$ & $-4538(9)$ & $7641(8)$ & $-8121(6)$ & $68(2)$ \\
$\mathrm{I}(1)$ & $-6859(1)$ & $11217(1)$ & $-8774(1)$ & $60(1)$ \\
$\mathrm{O}(1)$ & $-2086(8)$ & $7575(7)$ & $-5538(6)$ & $62(1)$ \\
$\mathrm{N}(1)$ & $481(8)$ & $7177(7)$ & $-2752(6)$ & $46(1)$ \\
$\mathrm{C}(2)$ & $1707(11)$ & $6888(11)$ & $-1516(8)$ & $59(2)$ \\
$\mathrm{C}(3)$ & $1692(12)$ & $5287(11)$ & $-978(8)$ & $64(2)$ \\
$\mathrm{C}(4)$ & $433(11)$ & $3984(10)$ & $-1672(8)$ & $55(2)$ \\
$\mathrm{C}(5)$ & $-2162(12)$ & $2857(9)$ & $-3713(9)$ & $58(2)$ \\
$\mathrm{C}(6)$ & $-3396(11)$ & $3099(10)$ & $-5051(9)$ & $60(2)$ \\
$\mathrm{C}(7)$ & $-3335(10)$ & $4674(10)$ & $-5618(8)$ & $53(2)$ \\
$\mathrm{C}(8)$ & $-2123(9)$ & $6059(9)$ & $-4938(7)$ & $45(1)$ \\
$\mathrm{C}(9)$ & $-842(8)$ & $5883(8)$ & $-3555(7)$ & $39(1)$ \\
$\mathrm{C}(10)$ & $-880(10)$ & $4218(9)$ & $-2979(7)$ & $47(2)$ \\
$\mathrm{C}(11)$ & $566(13)$ & $8976(9)$ & $-3194(9)$ & $61(2)$ \\
\hline
\end{tabular}

$U(\mathrm{eq})$ is defined as one third of the trace of the orthogonalized $U i j$ tensor. resolution of $\left.2 \mathrm{~cm}^{-1}\right)$. For the solution measurements, a cell with $\mathrm{KBr}$ windows (layer thickness: $0.20 \mathrm{~mm}$ and the concentration of the samples $0.025 \mathrm{~mol} \mathrm{dm}^{-3}$ ) was used.

The ${ }^{1} \mathrm{H}$ NMR measurements in DMSO- $d_{6}$ were carried out at the operating frequency $300.075 \mathrm{MHz}$; flip angle, $\mathrm{pw}=45^{\circ}$; spectral width, $\mathrm{sw}=4500 \mathrm{~Hz}$; acquisition time, at $=2.0 \mathrm{~s}$; relaxation delay, $d_{1}=1.0 \mathrm{~s} ; T=293.0 \mathrm{~K}$ and using TMS as the internal standard. No window function or zero filing was used. Digital resolution $=0.2 \mathrm{~Hz}$ per point

\subsection{Determination of $p K_{a}$ values}

The $\mathrm{p} K_{\mathrm{a}}$ value of the hydroxyl group of 8-hydroxyquinolinium iodide was determined by potentiometric titration of its $0.01 \mathrm{~mol} \mathrm{dm}^{-3}$ aqueous solution with $0.1 \mathrm{M} \mathrm{KOH}$. The potentiometric measurements were carried out at $25 \pm 0.5^{\circ} \mathrm{C}$ in an atmosphere of purified argon, using a pH-meter N517 (Mera-Tronic) equipped with a glass combined electrode OSH-10.

\section{Results and discussion}

The structure of the hydrogen-bonded complex studied with the atomic labelling is given in Fig. 1. The molecular structure of this $\left[\left(\mathrm{C}_{10} \mathrm{H}_{10} \mathrm{NO}\right)^{+} \mathrm{I}^{-} \cdot \mathrm{H}_{2} \mathrm{O}\right]$ complex, has been confirmed by the molecular dimensions, listed in Table 3 . The quinolidinium rings system is nearly planar - the largest distortions from planarity are in the region of $\mathrm{N}(1)$ atom, as apparent from the torsion angles listed in Table 4.

\subsection{X-ray crystallography}

The crystal structure of $\left[\left(\mathrm{C}_{10} \mathrm{H}_{10} \mathrm{NO}\right)^{+} \mathrm{I}^{-} \cdot \mathrm{H}_{2} \mathrm{O}\right]$ is isostructural with that of $\left[\left(\mathrm{C}_{10} \mathrm{H}_{10} \mathrm{NO}\right)^{+} \mathrm{Cl}^{-} \cdot \mathrm{H}_{2} \mathrm{O}\right]$ reported by Rømming and Uggerud [12]: the crystals are triclinic, space group $P \overline{1}$, with two formula units per unit-cell (Table 1). These two formula units are hydrogen-bonded to form a dimer shown in Fig. 2. The $\mathrm{O}(1)-\mathrm{H}$ hydroxyl group is bonded to the $\mathrm{O}(1 \mathrm{~W})$ oxygen atom of a water molecule, which in turn forms

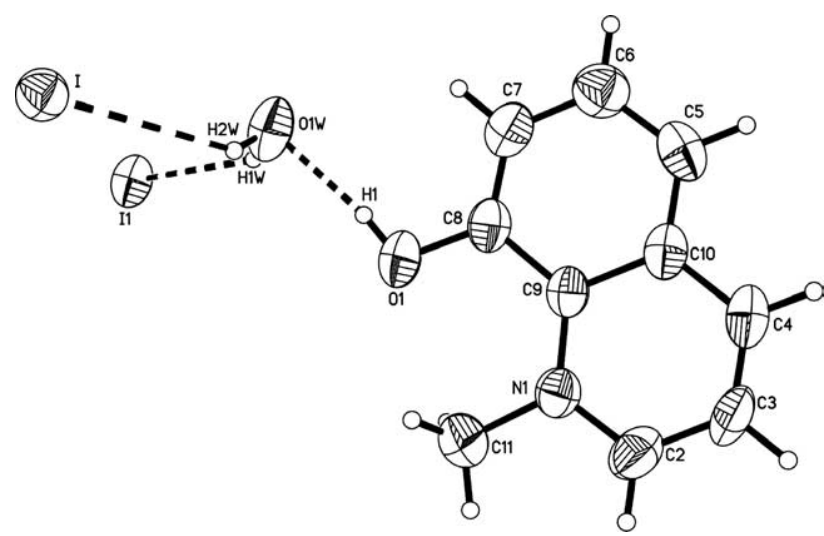

Fig. 1. The formula of 8-hydroxy-1-methylquinolinium iodide monohydrate. In this drawing, one symmetry-generated I atom has been added to illustrate the H-bonding pattern of the water molecule. 
Table 3

Bond lengths $(\AA)$ and angles $\left({ }^{\circ}\right)$

\begin{tabular}{ll}
\hline $\mathrm{O}(1)-\mathrm{C}(8)$ & $1.340(8)$ \\
$\mathrm{N}(1)-\mathrm{C}(2)$ & $1.337(9)$ \\
$\mathrm{N}(1)-\mathrm{C}(9)$ & $1.385(8)$ \\
$\mathrm{N}(1)-\mathrm{C}(11)$ & $1.493(9)$ \\
$\mathrm{C}(2)-\mathrm{C}(3)$ & $1.379(11)$ \\
$\mathrm{C}(3)-\mathrm{C}(4)$ & $1.334(12)$ \\
$\mathrm{C}(4)-\mathrm{C}(10)$ & $1.404(10)$ \\
$\mathrm{C}(5)-\mathrm{C}(10)$ & $1.384(11)$ \\
$\mathrm{C}(5)-\mathrm{C}(6)$ & $1.397(12)$ \\
$\mathrm{C}(6)-\mathrm{C}(7)$ & $1.370(11)$ \\
$\mathrm{C}(7)-\mathrm{C}(8)$ & $1.358(10)$ \\
$\mathrm{C}(8)-\mathrm{C}(9)$ & $1.432(9)$ \\
$\mathrm{C}(9)-\mathrm{C}(10)$ & $1.439(9)$ \\
$\mathrm{C}(2)-\mathrm{N}(1)-\mathrm{C}(9)$ & $121.7(6)$ \\
$\mathrm{C}(2)-\mathrm{N}(1)-\mathrm{C}(11)$ & $116.7(6)$ \\
$\mathrm{C}(9)-\mathrm{N}(1)-\mathrm{C}(11)$ & $121.6(6)$ \\
$\mathrm{N}(1)-\mathrm{C}(2)-\mathrm{C}(3)$ & $121.2(7)$ \\
$\mathrm{C}(4)-\mathrm{C}(3)-\mathrm{C}(2)$ & $120.6(7)$ \\
$\mathrm{C}(3)-\mathrm{C}(4)-\mathrm{C}(10)$ & $120.4(7)$ \\
$\mathrm{C}(10)-\mathrm{C}(5)-\mathrm{C}(6)$ & $119.2(7)$ \\
$\mathrm{C}(7)-\mathrm{C}(6)-\mathrm{C}(5)$ & $120.0(7)$ \\
$\mathrm{C}(8)-\mathrm{C}(7)-\mathrm{C}(6)$ & $123.3(7)$ \\
$\mathrm{O}(1)-\mathrm{C}(8)-\mathrm{C}(7)$ & $121.6(6)$ \\
$\mathrm{O}(1)-\mathrm{C}(8)-\mathrm{C}(9)$ & $119.4(6)$ \\
$\mathrm{C}(7)-\mathrm{C}(8)-\mathrm{C}(9)$ & $118.9(6)$ \\
$\mathrm{N}(1)-\mathrm{C}(9)-\mathrm{C}(8)$ & $125.1(6)$ \\
$\mathrm{N}(1)-\mathrm{C}(9)-\mathrm{C}(10)$ & $117.2(6)$ \\
$\mathrm{C}(8)-\mathrm{C}(9)-\mathrm{C}(10)$ & $117.7(6)$ \\
$\mathrm{C}(5)-\mathrm{C}(10)-\mathrm{C}(4)$ & $120.3(7)$ \\
$\mathrm{C}(5)-\mathrm{C}(10)-\mathrm{C}(9)$ & $120.8(7)$ \\
$\mathrm{C}(4)-\mathrm{C}(10)-\mathrm{C}(9)$ & $118.9(7)$ \\
\hline & \\
& \\
\hline
\end{tabular}

hydrogen bonds with two iodide anions with the water molecule being a proton donor: $\mathrm{O}(1 \mathrm{~W})-\mathrm{H}(1 \mathrm{~W}) \cdots \mathrm{I}(1)$ and $\mathrm{O}(1 \mathrm{~W})-\mathrm{H}(2 \mathrm{~W}) \cdots \mathrm{I}(1)^{i}$ at the symmetry - equivalent position $-x-1,2-y,-z-2$. These two iodide anions are again hydrogen-bonded both to one water molecule which is further hydrogen-bonded to the hydroxyl group of the organic cation, both transformed by the same symmetry code, to form a centrosymmetric dimer. The geometries of the hydrogen bonds are described in Table 5. The $\mathrm{O}(1)-\mathrm{H} \cdots \mathrm{O}(1 \mathrm{~W})$ hydrogen bond $(2.657 \AA)$ is slightly longer than that in the hydrochloride analogue (2.631 $\AA$ [12]). Also, like in the hydrochloride analogue, the neighbouring aromatic quinolinium systems are

Table 4

Selected torsion angles $\left({ }^{\circ}\right)$

\begin{tabular}{ll}
\hline $\mathrm{C}(11)-\mathrm{N}(1)-\mathrm{C}(2)-\mathrm{C}(3)$ & $177.0(8)$ \\
$\mathrm{C}(6)-\mathrm{C}(7)-\mathrm{C}(8)-\mathrm{O}(1)$ & $178.9(7)$ \\
$\mathrm{C}(2)-\mathrm{N}(1)-\mathrm{C}(9)-\mathrm{C}(8)$ & $-175.4(7)$ \\
$\mathrm{C}(11)-\mathrm{N}(1)-\mathrm{C}(9)-\mathrm{C}(8)$ & $6.9(10)$ \\
$\mathrm{C}(11)-\mathrm{N}(1)-\mathrm{C}(9)-\mathrm{C}(10)$ & $-175.8(6)$ \\
$\mathrm{O}(1)-\mathrm{C}(8)-\mathrm{C}(9)-\mathrm{N}(1)$ & $-0.1(10)$ \\
$\mathrm{C}(7)-\mathrm{C}(8)-\mathrm{C}(9)-\mathrm{N}(1)$ & $179.1(6)$ \\
$\mathrm{O}(1)-\mathrm{C}(8)-\mathrm{C}(9)-\mathrm{C}(10)$ & $-177.5(6)$ \\
$\mathrm{C}(6)-\mathrm{C}(5)-\mathrm{C}(10)-\mathrm{C}(4)$ & $-176.6(7)$ \\
$\mathrm{C}(3)-\mathrm{C}(4)-\mathrm{C}(10)-\mathrm{C}(5)$ & $178.7(8)$ \\
$\mathrm{N}(1)-\mathrm{C}(9)-\mathrm{C}(10)-\mathrm{C}(5)$ & $179.8(6)$ \\
$\mathrm{C}(8)-\mathrm{C}(9)-\mathrm{C}(10)-\mathrm{C}(4)$ & $176.0(6)$ \\
\hline
\end{tabular}

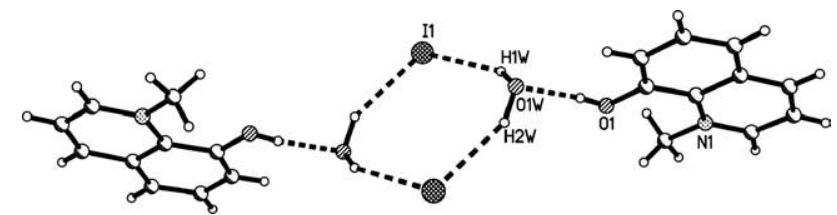

Fig. 2. The dimeric structure of 8-hydroxy-1-methylquinolinium iodide monohydrate illustrating the H-bonding scheme in the crystal.

stacked with the interplanar distance of $3.49 \AA$, thus slightly longer compared to $3.35 \AA$ in $\left[\left(\mathrm{C}_{10} \mathrm{H}_{10} \mathrm{NO}\right)^{+} \mathrm{Cl}^{-} \cdot \mathrm{H}_{2} \mathrm{O}\right]$ hydrate [12]. The stacked systems are related by a centre of inversion, so the symmetry restricts the quinolidinium rings to be parallel, and the dipole moments of the cations to be antiparallel, which is electrostatically favourable for the stacking (Fig. 3).

\subsection{Spectroscopic measurements}

Fig. 4a-c compares the IR spectra of the 8-hydroxy-1methylquinolinium iodide monohydrate in the solid state nujol/ fluorolube, $\mathrm{KBr}$ pellet and in the acetonitrile solution, respectively.

The IR spectra of the 8-hydroxy-1-methylquinolinium iodide monohydrate in nujol/fluorolube and $\mathrm{KBr}$ pellet (Fig. 4a and b) are comparable and they are in excellent agreement with the crystal structure analysis. Both spectra

Table 5

Dimensions of the hydrogen bonds $\left(\AA\right.$ and $^{\circ}$ ); the applied symmetry codes are: (i) $-x-1,-y+2,-z-2$

\begin{tabular}{lllll}
\hline $\mathrm{D}-\mathrm{H} \cdots \mathrm{A}$ & $d(\mathrm{D}-\mathrm{H})$ & $d(\mathrm{H} \cdots \mathrm{A})$ & $d(\mathrm{D} \cdots \mathrm{A})$ & $<(\mathrm{DHA})$ \\
\hline $\mathrm{O}(1)-\mathrm{H}(1) \cdots \mathrm{O}(1 \mathrm{~W})$ & 0.82 & 1.84 & $2.657(8)$ & 172 \\
$\mathrm{I}(1) \cdots \mathrm{H}(1 \mathrm{~W})-\mathrm{O}(1 \mathrm{~W})$ & 1.00 & 2.70 & $3.581(6)$ & 147 \\
$\mathrm{I}(1) \cdots \mathrm{H}(2 \mathrm{~W})-\mathrm{O}(1 \mathrm{~W})^{\mathrm{i}}$ & 1.00 & 2.78 & $3.537(6)$ & 133 \\
\hline
\end{tabular}

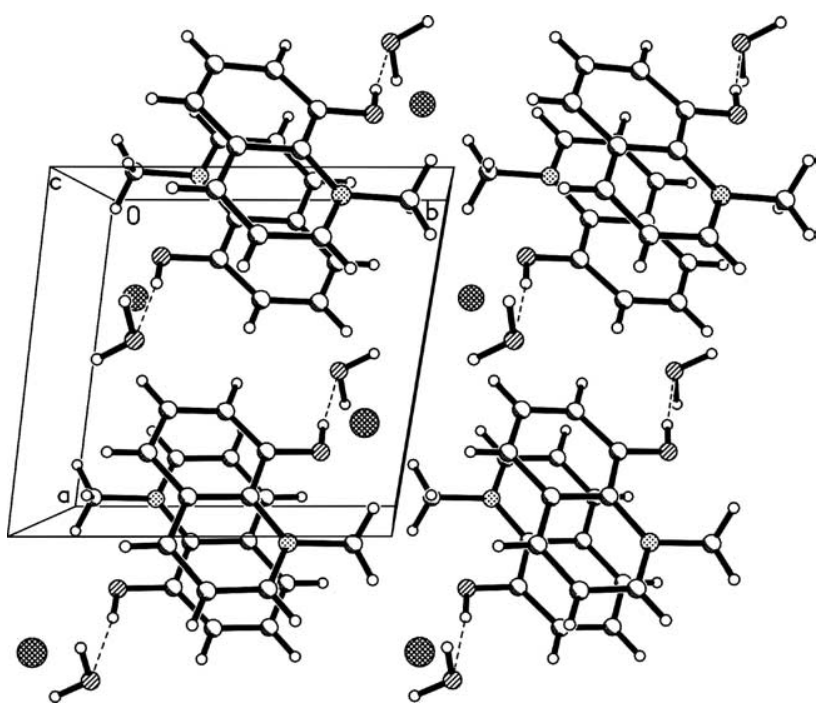

Fig. 3. Autostereogram [26] of the crystal packing of 8-hydroxy-1methylquinolinium iodide monohydrate viewed along [100] crystal direction. 

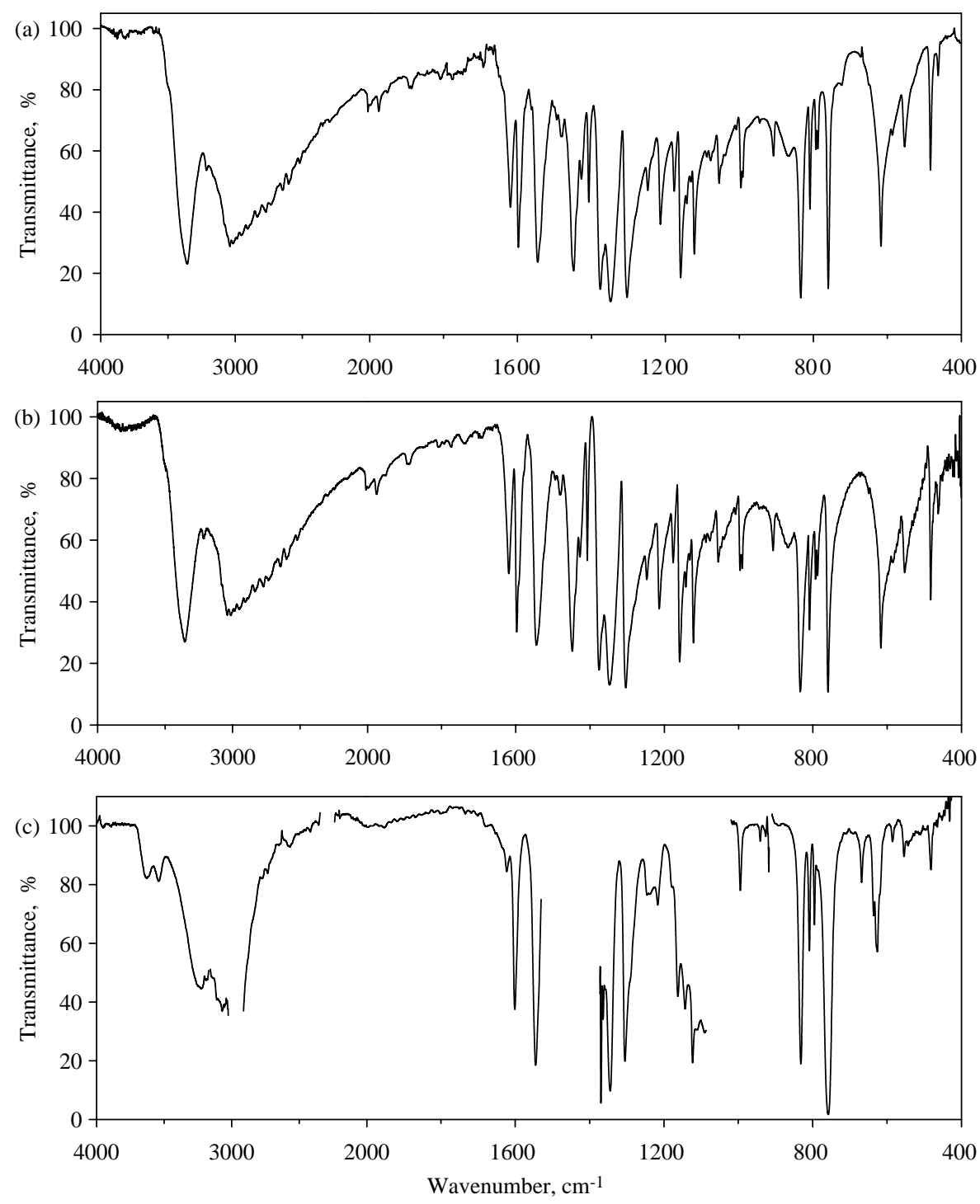

Fig. 4. FT-IR spectra of the 8-hydroxy-1-methylquinolinium iodide monohydrate crystals in: (a) nujol, fluorolube mulls, (b) KBr pellet, and (c) acetonitrile solution.

feature an intense and broad band with a maximum at ca. $2800 \mathrm{~cm}^{-1}$, corresponding to the proton vibrations in relatively weak hydrogen bonds formed between $8-\mathrm{OH}$ group and oxygen atom of water molecule. An intense and relatively sharp band with a maximum at $3355 \mathrm{~cm}^{-1}$ is assigned to the stretching vibrations of the $\mathrm{OH}$ group in the very weak intermolecular $\mathrm{O}-\mathrm{H} \cdots \mathrm{I}^{-}$hydrogen bond formed between the water molecule and the $\mathrm{I}^{-}$anion. Such an assignment corresponds very well with the hydrogen bond parameters given in Table 5.

In the IR spectrum of the 8-hydroxy-1-methylquinolinium iodide mono-hydrate in acetonitrile (maximal concentration, Fig. 4c), one intense band with a maximum at ca. $3250 \mathrm{~cm}^{-1}$ assigned to the proton stretching vibrations in the

Table 6

Chemical shifts (ppm) and coupling constants (Hz) of the protons in the ${ }^{1} \mathrm{H}$ NMR spectra of 8-hydroxyquinoline (8Q) and 8-hydroxy-1-methylquinolinium iodide (8QMeI) in DMSO- $d_{6}$

\begin{tabular}{|c|c|c|c|c|c|c|c|c|c|c|c|c|c|c|}
\hline \multirow[t]{2}{*}{ Comp. } & \multicolumn{8}{|c|}{$\delta(\mathrm{ppm})$} & \multicolumn{6}{|l|}{$J \mathrm{~Hz}$} \\
\hline & $\mathrm{H} 2$ & $\mathrm{H} 3$ & $\mathrm{H} 4$ & H5 & H6 & $\mathrm{H} 7$ & $\mathrm{CH}_{3}$ & $\mathrm{OH}$ & $J_{23}$ & $J_{34}$ & $J_{24}$ & $J_{56}$ & $J_{67}$ & $J_{57}$ \\
\hline $8 Q$ & 8.86 & 7.56 & 8.33 & 7.40 & 7.46 & 7.10 & - & 9.97 & 4.24 & 8.25 & 1.89 & 8.24 & 7.07 & 1.65 \\
\hline $8 \mathrm{QMeI}$ & 9.30 & 8.04 & 9.13 & 7.85 & 7.81 & 7.54 & 4.83 & 11.74 & 5.77 & 8.51 & 1.37 & 8.24 & 7.14 & 2.19 \\
\hline$\Delta$ & 0.44 & 0.48 & 0.80 & 0.45 & 0.35 & 0.44 & & 1.77 & & & & & & \\
\hline
\end{tabular}

$\Delta$, differences between the respective chemical shifts. 
Table 7

Chemical shifts in the ${ }^{13} \mathrm{C}$ NMR spectra of 8-hydroxyquinoline (8Q) and 8-hydroxy-1-methylquinolinium iodide (8QMeI) in DMSO- $d_{6}$

\begin{tabular}{|c|c|c|c|c|c|c|c|c|c|c|}
\hline \multirow[t]{2}{*}{ Comp. } & \multicolumn{10}{|l|}{$\delta(\mathrm{ppm})$} \\
\hline & $\overline{\mathrm{C} 2}$ & C3 & $\mathrm{C} 4$ & $\mathrm{C} 5$ & C6 & $\mathrm{C} 7$ & $\mathrm{C} 8$ & C9 & $\mathrm{C} 10$ & $\mathrm{CH}_{3}$ \\
\hline $8 Q$ & 149.90 & 121.63 & 135.84 & 117.56 & 127.32 & 111.14 & 153.11 & 138.31 & 128.62 & - \\
\hline$\Delta$ & 1.23 & -0.01 & 11.02 & 2.87 & 3.15 & 8.35 & -3.21 & -6.47 & 0.71 & \\
\hline
\end{tabular}

$\Delta$, differences between the respective chemical shifts.

intermolecular $8-\mathrm{O}-\mathrm{H} \cdots \mathrm{I}^{-}$weak hydrogen bonds is observed. Besides this band, there are two bands of very weak intensity at 3637 and $3545 \mathrm{~cm}^{-1}$, assigned to the $\nu_{\text {as }}(\mathrm{OH})$ and $\nu_{\mathrm{s}}(\mathrm{OH})$ vibrations of water molecule in acetonitrile, respectively. Such an assignment has been previously often discussed for pure water and for ice $[17,18]$, as well as for water molecules in different environments [19]. These results indicate clearly that the water molecules in 8-hydroxy-1-methylquinolinium iodide mono-hydrate in acetonitrile exists as a free molecule (bonded to acetonitrile) [20], i.e. that the structure observed for the solid state is no longer observed in the solution. The same observation is made on the basis of the NMR spectra in DMSO- $d_{6}$ solutions.

For the sake of comparison, Tables 6 and 7 present the ${ }^{1} \mathrm{H}$ and ${ }^{13} \mathrm{C}$ NMR data of 8-hydroxy-1-methylquinolinium iodide monohydrate and 8-hydroxyquinoline. The assignment of the respective signals was made using the dimensional (COSY and HETCOR) methods. These data demonstrate that both types of ${ }^{1} \mathrm{H}$ and ${ }^{13} \mathrm{C}$ signals are strongly shifted toward higher parts per million values as a result of formation of the quaternary cations, except for the signals of $\mathrm{C}(8)$ and $\mathrm{C}(9)$ carbon atoms. Such effects of chemical shifts are very well known in literature [21-24]. The most interesting results observed in the NMR spectra are the chemical shifts of the proton of 8-OH group and those of the protons of one water molecule in the spectrum of the 8-hydroxy-1-methylquinolinium iodide monohydrate. The signal of the $8-\mathrm{OH}$ proton in the spectrum of 8-hydroxyquinoline is found at $9.97 \mathrm{ppm}$ (in DMSO- $d_{6}$ solution) as relatively sharp one and the corresponding signal in the spectrum of 8-hydroxy-1-methylquinolinium iodide monohydrate is observed at $11.74 \mathrm{ppm}$. This result indicates that in the latter, the $8-\mathrm{OH}$ proton is hydrogen bonded with the solvent (DMSO- $d_{6}$ ) stronger then in the former. The observed large difference between the chemical shifts of these $\mathrm{OH}$ protons can be explained by changes in their proton donor properties, which are very well reflected by the changes in their $\mathrm{p} K_{\mathrm{a}}$ values. The $\mathrm{p} K_{\mathrm{a}}$ value of $8-\mathrm{OH}$ group in 8-hydroxy-1methylquinolinium ion measured by us is $6.96 \pm 0.03$ (see Section 2) and is in a quite close agreement with literature data $(6.8-7.0[9,14,25])$. It is noteworthy that this value is almost three units lower than that for the parent molecule 8-hydroxyquinoline, i.e. 9.89 [25].

In the ${ }^{1} \mathrm{H}$ NMR spectrum of 8 -hydroxy-1-methylquinolinium iodide mono-hydrate, the signal assigned to the protons of the water molecule is observed at $3.48 \mathrm{ppm}$ indicating clearly that this molecule is now bonded only to the solvent molecules. These results demonstrate that the structure of the hydrate changes after its dissolution in acetonitrile or DMSO- $d_{6}$.

In conclusion, the structure of 8-hydroxy-1-methylquinolinium iodide mono-hydrate is very similar to that of the earlier studied chloride analogue [12]. Within these dimeric structures, the $8-\mathrm{OH}$ groups are hydrogen-bonded to the oxygen atom of the water molecules and the protons of these water molecules are further hydrogen bonded with $\mathrm{Cl}^{-}$or $\mathrm{I}^{-}$anions. In the system studied the hydrogen bonds are slightly weaker than those of the chloride analogue.

\section{References}

[1] E. Bartoszak-Adamska, G. Wojciechowski, M. Jaskólski, B. Brzezinski, J. Mol. Struct. 595 (2001) 21.

[2] G. Wojciechowski, M. Ratajczak-Sitarz, A. Katrusiak, B. Brzezinski, J. Mol. Struct. 613 (2002) 73.

[3] G. Wojciechowski, M. Ratajczak-Sitarz, A. Katrusiak, B. Brzezinski, J. Mol. Struct. 613 (2002) 83.

[4] G. Wojciechowski, M. Ratajczak-Sitarz, A. Katrusiak, B. Brzezinski, J. Mol. Struct. 741 (2005) 37.

[5] C.J. Dammond, F. Grieser, T.W. Healy, J. Phys. Chem. 92 (1988) 2604.

[6] E. Bardez, A. Chatelain, B. Larrey, B. Valeur, J. Phys. Chem. 98 (1994) 2357.

[7] S. Kumoi, K. Oyama, T. Yana, H. Kobayashi, K. Ueno, Talanta 17 (1970) 319.

[8] I.S. Joffe, N.A. Selezneva, Zh. Obshch. Khim. 30 (1960) 91.

[9] A.K. Prince, Arch. Biochem. Biophys. 113 (1966) 195.

[10] J.P. Saxena, W.H. Stafford, W.L. Stafford, J. Chem. Soc. (1959) 1579.

[11] R.G.W. Hollinghead, Oxine and its Derivatives, Butterworths, London, 1954/1956.

[12] C. Rømming, E. Uggerud, Acta Chem. Scand. B 37 (1983) 791.

[13] M. Ueda, Z.A. Schelly, Langmuir 5 (1989) 1005.

[14] L.P. Novaki, O.A. El Seoudi, Ber. Bunsenges. Phys. Chem. 100 (1996) 648.

[15] G. Sheldrick, SHELXs-97. Program for Crystal Structure Solution, University of Goettingen, 1997.

[16] G. Sheldrick, sheLXL-97. Program for Crystal Structure Refinement, University of Goettingen, 1997.

[17] G.E. Walrafen, J. Chem. Phys. 44 (1966) 1546

[18] M.J. Taylor, E. Walley, J. Chem. Phys. 40 (1964) 1660.

[19] M. Ilczyszyn, D. Godzisz, M.M. Ilczyszyn, J. Mol. Struct. 611 (2002) 103.

[20] W.E. Greinacher, W. Luttke, R. Mecke, Z. Electrochem. 59 (1955) 23.

[21] U. Vögeli, W. von Philipsborn, Org. Magn. Reson. 5 (1973) 551.

[22] G. Baebieri, R. Benassi, P. Lazzeretti, L. Schenetti, F. Taddei, Org. Magn. Reson. 7 (1975) 451.

[23] Y. Takeuchi, N. Dennis, Org. Magn. Reson. 8 (1976) 21.

[24] M.R. Del Giudice, G. Settimj, M. Delfini, Tetrahedron 40 (1984) 4087.

[25] S.F. Manson, J. Chem. Soc. (1957) 5010; S.F. Manson, J. Chem. Soc. (1958) 674.

[26] A. Katrusiak, J. Mol. Graph. Model.19(2001) 362. 